instances six, serotypes. In only two were the maximum titres against the serotypes responsible for the original infection.

\section{Discussion}

Our results suggest that the long-term prognosis after the acute renal lesion of leptospirosis is good. Thus in the British patients all the results of renal function tests were normal except for a slightly reduced creatinine clearance in one man; as the serum creatinine level and other results in him were normal the significance of this isolated finding is doubtful. Another man developed hypertension, but renal damage did not appear to be the cause. One group of Gurkha patients had normal creatinine clearances but all did not concentrate urine adequately, while in the others these findings were reversed; since each abnormality was confined to one group it seems likely that these discrepancies reflect incomplete dehydration and incomplete urine collection respectively.

As intravenous pyelograms were performed in only four patients, and renal biopsy in none, we cannot be certain that permanent minor anatomical damage to the kidneys has not occurred; but as the individual results were not influenced by the severity of the initial renal lesion or the time interval before reassessment it is unlikely that there is an active process present causing progressive destruction of renal tissue.

The finding of leptospiral agglutinins in the sera of the 12 patients examined is of interest, though in only two did the serological pattern parallel that of the original infection. Hart (1967), using the sensitized erythrocyte lysis test, has shown that a small proportion of soldiers serving in jungle areas in South-east Asia develop a rising titre of leptospiral antibodies without clinical evidence of infection, and our patients have served in this area on several occasions since their original illness. It is thus conceivable that they have acquired subclinical infections during this time and that this explains the serological findings. As, however, all our patients showed significant titres of agglutinins, and none of them had a clinical attack, which would be surprising if they were frequently exposed to infection, this explanation may be too facile. Further investigation of this point is required.

\section{Summary}

Renal function was studied in 44 soldiers who had contracted leptospirosis in South-east Asia up to 14 years previously. The findings suggest that renal function is now normal, and individual results do not reflect the severity of the initial renal damage or the time interval before reassessment.

The sera of 12 patients were examined for leptospiral agglutinins. All showed significant titres, but in only two were these against the serotype responsible for the original illness. These results may possibly reflect subclinical leptospiral infections contracted during later periods of service in the same area, but the present evidence is insufficient to allow firm conclusions to be drawn.

We wish to thank Dr. Gordon Smith, Director M.R.E., Porton, and Major-General R. J. G. Morrison, Consultant Physician to the Army, for suggesting and encouraging this investigation; Dr. L. H. Turner for the serological results and advice; Captain K. Hedges, R.A.M.C., for his help in arranging for the investigation of patients under his care; and the Director-General, Army Medical Services, for permission to use case records.

Requests for reprints should be sent to Major B. Simpson.

\section{REFERENCES}

Alexander, A. D., Evans, L. B., Toussaint, A. J., Marchwicki, R. H., and McCrumb, F. R., jun. (1957). Amer. F. trop. Med. Hyg., 6, 871. de Brito, T., et al. (1965). Ibid., 14, 397.

Gsell, O. (1952). Leptospirosen. Berne.

Hart, R. J. C. (1967). To be published.

Johnson, D. W. (1950). Med. f. Aust., 2, 724.

Levis, D. G. (1957). Proc. roy. Soc. Med., 50, 119.

Mackay-Dick, J., and Robinson, J. F. (1957). f. roy. Army med. Cps, $103,186$.

Penna, D., de Brito, T., Aguiar Pupo, A., Marcondes Machado, M., Ayroza Galvão, P. A., and Soares de Almeida, S. (1963). Amer. $\tilde{\jmath}$. trop. Med. Hyg., 12, 896.

Ross Russell, R. W. (1959). Ann. trop. Med. Parasit., 53, 416.

Spînu, I., Topciu, Vl., Trinh Thi Hang Quy, Vo van Hung, Chau xuan Luong, and Le van Tuyen (1962). Arch. roum. Path. exp., 21, 763. Van Theil, P. H. (1948). The Leptospiroses, Leiden.

Trimble, A. P. (1957). Proc. roy. Soc. Med., 50, 125.

Varley, H. (1962). Practical Clinical Biochemistry, 3rd ed., pp. 112, 151,153 . London.

\title{
Effect of Medical and Surgical Vagotomy on Intrinsic Factor Secretion
}

\author{
J. F. ADAMS, * V.R.D., M.D., F.R.C.P.ED., F.R.C.P.GLASG.; A. G. COX,*† M.D., F.R.C.S.ED. \\ ELIZABETH H. KENNEDY,*‡ B.SC. ; J. THOMPSON,*§ M.B., M.R.C.P.GLASG.
}

Brit. med. F., 1967, 3, 473-476

The recent development of in-vitro techniques for the assay of gastric intrinsic factor has made possible the study of the effects of various pharmacological and surgical manœuvres on this facet of gastric secretory function. Using one such technique, we have studied the effects of pharmacological vagal blockade- " medical vagotomy"-in a group of patients with proved duodenal ulceration, and in some of these have also studied the effects of section of the vagus nerves.

\section{Material and Methods}

Twenty-six patients (23 men aged $22-60$ and 3 women aged $42-48$ ) with the clinical and radiological features of chronic duodenal ulceration were studied before operation, and further studies were made in 15 of them after operation. Vagotomy and pyloroplasty were performed on six men and one woman and vagotomy and gastrojejunostomy on six men and two women. The augmented histamine test was carried out in 26 cases before operation and in 15 after operation. Medical vagotomy was carried out in 25 cases before operation. The insulin test was done in 15 cases after operation. The choice of pyloroplasty or gastrojejunostomy was determined by a randomization procedure. The completeness of surgical vagotomy was confirmed in all cases by an insulin test.

The augmented histamine test (Kay, 1953) was performed after an overnight fast. Gastric aspiration was maintained by

\footnotetext{
* Southern General Hospital and University Department of Surgery, Western Infirmary, Glasgow.

† Now Senior Lecturer in Surgery, Royal Postgraduate Medical School, London.

‡ Now Scientific Officer, National Engineering Laboratory, East Kilbride, Lanarkshire. $\$$ Now Lecturer in Dermatology, University and Western Infirmary,
} 
continuous suction. After collection of basal secretion in 15minute periods for one hour, $100 \mathrm{mg}$. of mepyramine maleate was injected intramuscularly. Thirty minutes later histamine acid phosphate, $0.04 \mathrm{mg} . / \mathrm{kg}$. body weight, was injected subcutaneously and gastric aspiration was continued for a further hour, again in 15-minute collection periods.

The medical vagotomy test (Gillespie and Kay, 1961) was carried out on another day. This differed from the standard augmented histamine test in that a combined intramuscular injection of $50 \mathrm{mg}$. of hexamethonium bromide, and $0.325 \mathrm{mg}$. of atropine, was given at the beginning of the test.

The insulin test was performed with a standard dose of 20 units of soluble insulin given intravenously after collection of three 15-minute specimens of spontaneous secretions. After the injection gastric aspiration was continued for two hours. Vagotomy was regarded as complete only if the acid concentration failed to rise 20 or more $\mathrm{mEq} / \mathrm{l}$. over the maximal basal level.

The volume and $p \mathrm{H}$ of all specimens of gastric juice were measured. The amount of acid was determined by titration to $p \mathrm{H} 7$ with $\mathrm{N} / 10 \mathrm{NaOH}$, phenol red being used as the indicator. Intrinsic factor assays were performed by the method of Gottlieb et al. (1965). Several sera containing antibody to intrinsic factor were used, all being of high potency. When the total binding exceeded $75 \%$ of the amount of radioactive cyanocobalamin added (usually $7.5 \mathrm{~m} \mu \mathrm{g}$.) the procedure was repeated with half the normal amount of neutralized gastric juice: if the total binding still exceeded $75 \%$ of the amount of radioactive cyanocobalamin added then the procedure was repeated with half the normal amount of neutralized gastric juice and double the normal amount of radioactive cyanocobalamin. For convenience we adopted the convention of expressing intrinsic factor activity in terms of units, one unit being taken as the specific intrinsic factor binding of $1 \mathrm{~m} \mu \mathrm{g}$. of radioactive cyanocobalamin.

The results were analysed by standard statistical methods.

\section{Results}

All results are given as hourly values, representing spontaneous secretion ("basal hour"), the augmented histamine response ("augmented histamine hour"), and the response to histamine after medical vagotomy (" medical vagotomy hour").

\section{Effect of Histamine Stimulation}

The mean values for volume, acid, intrinsic factor output, and intrinsic factor concentration were all significantly higher $(P<0.01)$ in the augmented histamine hour than in the basal hour (Table I).

\section{Correlation between Acid and Intrinsic Factor Output}

An insignificant correlation was found between the mean values for acid and intrinsic factor in the basal hours, both before and after operation. However, a significant $(P<0.01)$ correlation was found between these two measurements in the augmented histamine hours both before and after operation, and also in the medical vagotomy hour (Table II).

TABLE II.-Correlation and Regression Equations

\begin{tabular}{|c|c|c|c|c|}
\hline Series & Period & $\begin{array}{l}\text { Regression of } y \text { (I.F.) } \\
\text { on } x \text { (Acid) }\end{array}$ & $\begin{array}{l}\text { No. of } \\
\text { Patients }\end{array}$ & $\mathbf{r}$ \\
\hline \multirow{2}{*}{ All patients } & Histamine hour ... & $y=3.085 x+60.045$ & 26 & 0.551 \\
\hline & $\begin{array}{c}\text { Medical vagotomy } \\
\text { hour }\end{array}$ & $y=4.773 x+34.629$ & 25 & 0.535 \\
\hline \multirow{3}{*}{$\begin{array}{r}\text { Surgical } \\
\text { group }\end{array}$} & $\begin{array}{l}\text { Preoperative hist- } \\
\text { amine hour . } \\
\text { Medical vagotomy }\end{array}$ & $y=4.926 x+25.947$ & 15 & 0.693 \\
\hline & hour & $y=7 \cdot 419 x+15 \cdot 0965$ & 14 & 0.751 \\
\hline & amine hour & $y=7.759 x+18.652$ & 15 & 0.762 \\
\hline
\end{tabular}

\section{Effect of Medical and Surgical Vagotomy}

The results are most conveniently considered in two groups. The first relates to the effect of medical vagotomy on the augmented histamine response. The second relates to the effect of surgical vagotomy on basal secretion and the augmented histamine response.

Medical Vagotomy.-The mean values for volume and acid were significantly less $(\mathrm{P}<0.01)$ in the medical vagotomy hour than in the augmented histamine hour. Differences in the mean values for intrinsic factor output and concentration did not

\begin{tabular}{|c|c|c|c|c|c|c|}
\hline \multirow[b]{2}{*}{ Case No. } & \multicolumn{2}{|c|}{$\begin{array}{c}\text { Augmented } \\
\text { Histamine Hour }\end{array}$} & \multicolumn{2}{|c|}{$\begin{array}{c}\text { Medical Vagotomy } \\
\text { Hour }\end{array}$} & \multicolumn{2}{|c|}{ Percentage Chang: } \\
\hline & $\begin{array}{c}\text { Acid } \\
\text { (mEq) }\end{array}$ & $\begin{array}{l}\text { I.F. } \\
\text { (mug. } \\
\text { Units) }\end{array}$ & $\begin{array}{c}\text { Acid } \\
(\mathrm{mEq})\end{array}$ & $\begin{array}{c}\text { I.F. } \\
\text { (murg. } \\
\text { Units) }\end{array}$ & Acid & I.F. \\
\hline $\begin{array}{r}1 \\
2 \\
3 \\
4 \\
5 \\
6 \\
7 \\
8 \\
9 \\
10 \\
11 \\
12 \\
13 \\
14 \\
15 \\
16 \\
17 \\
18 \\
19 \\
20 \\
21 \\
22 \\
23 \\
24 \\
25 \\
26\end{array}$ & $\begin{array}{l}32 \cdot 6 \\
23 \cdot 6 \\
19 \cdot 6 \\
21 \cdot 8 \\
52 \cdot 6 \\
41.3 \\
73 \cdot 6 \\
29 \cdot 9 \\
43 \cdot 2 \\
39 \cdot 2 \\
28 \cdot 3 \\
7 \cdot 3 \\
48 \cdot 2 \\
21 \cdot 8 \\
24 \cdot 4 \\
16 \cdot 3 \\
20 \cdot 8 \\
15 \cdot 0 \\
36 \cdot 1 \\
56 \cdot 8 \\
43 \cdot 9 \\
23 \cdot 9 \\
36 \cdot 2 \\
57.5 \\
24 \cdot 8 \\
34 \cdot 8\end{array}$ & $\begin{array}{r}19,110 \\
9,170 \\
10,351 \\
10,875 \\
16,311 \\
15,524 \\
19,023 \\
12,078 \\
10,619 \\
18,195 \\
15,000 \\
10,931 \\
16,593 \\
6,233 \\
12,765 \\
11,223 \\
13,984 \\
17,280 \\
35,838 \\
29,796 \\
18,589 \\
6,406 \\
12,412 \\
45,021 \\
17,485 \\
14,802\end{array}$ & $\begin{array}{r}13.7 \\
14.3 \\
7.0 \\
14.0 \\
34.2 \\
23.1 \\
44.3 \\
4.5 \\
20.2 \\
17.6 \\
13.5 \\
4.3 \\
26.6 \\
23.9 \\
14.5 \\
7.7 \\
10.3 \\
13.4 \\
21.1 \\
31.4 \\
16.7 \\
20.0 \\
18.8 \\
42.4 \\
21.1 \\
19.8\end{array}$ & $\begin{array}{r}9.564 \\
6,698 \\
4,096 \\
4,326 \\
10,523 \\
12,173 \\
14,827 \\
10,875 \\
6,919 \\
5,275 \\
5,, 300 \\
10,174 \\
17,929 \\
11,510 \\
12,705 \\
7,554 \\
13,937 \\
20,613 \\
30,125 \\
13,969 \\
9,466 \\
7,270 \\
38,280 \\
27,381 \\
6,088\end{array}$ & $\begin{array}{l}-58 \\
-39.4 \\
-64.3 \\
-35.8 \\
-35.0 \\
-44.1 \\
-39.8 \\
-84.9 \\
-53.2 \\
-55.1 \\
-52.3 \\
-41.0 \\
-44.8 \\
+9.6 \\
-40.5 \\
-52.7 \\
-50.4 \\
-10.6 \\
-41.5 \\
-44.7 \\
-61.9 \\
-16.3 \\
-48.0 \\
-26.2 \\
-14.9 \\
-43.1\end{array}$ & $\begin{array}{l}-50 \\
-27 \\
=60.1 \\
=60.2 \\
-35.5 \\
-21.6 \\
-22.1 \\
=9.3 \\
=34.8 \\
=71.0 \\
-64.7 \\
=6.9 \\
+8.1 \\
+84.6 \\
+13.2 \\
+45.9 \\
=19.3 \\
-42.5 \\
+11.1 \\
-24.8 \\
+47.8 \\
-41.4 \\
-14.9 \\
+56.6 \\
-58.8\end{array}$ \\
\hline $\begin{array}{l}\text { All cases } \\
\text { All except } \\
\text { Case } 15\end{array}$ & & & & & $\begin{array}{l}-42.9 \\
-43.0\end{array}$ & $\begin{array}{l}-20.6 \\
-20.6\end{array}$ \\
\hline
\end{tabular}

TABLE I.-Mean Hourly Values for Volume, Acid, Intrinsic Factor and Intrinsic Factor Concentration

\begin{tabular}{|c|c|c|c|c|c|c|c|c|c|c|c|c|c|c|c|c|c|c|c|c|c|c|c|c|c|c|}
\hline & & \multicolumn{5}{|c|}{ Basal Hour } & \multicolumn{5}{|c|}{ Post-Histamine Hour } & \multicolumn{5}{|c|}{ Medical Vagotomy Hour } & \multicolumn{5}{|c|}{ Postoperative Basal Hour } & \multicolumn{5}{|c|}{$\begin{array}{l}\text { Postoperative Post-Hist- } \\
\text { amine Hour }\end{array}$} \\
\hline & & $\dot{z}$ & गंड्वे & 䢓它 & 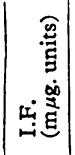 & 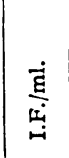 & $\dot{\mathrm{g}}$ & गं & 苞高 & 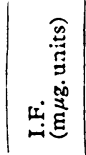 & 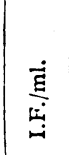 & $\dot{z}$ & iे & प्रुण & 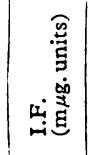 & 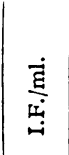 & $\dot{z}$ & $\dot{\overrightarrow{0}} \widehat{\overrightarrow{\dot{\theta}}}$ & 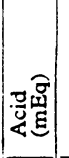 & 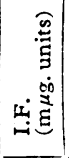 & 豆 & $\dot{\leftrightarrow}$ & >ंक्ष & 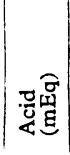 & 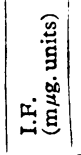 & $\underset{E}{E}$ \\
\hline 总总 & $\left\{\begin{array}{l}\text { No. } \\
\text { Mean } \\
\text { S.D. } \\
\text { S.E. }\end{array}\right.$ & 26 & $\begin{array}{r}r 26.84 \\
48.87 \\
9.58\end{array}$ & $\begin{array}{l}6.29 \\
3.88 \\
0.76\end{array}$ & $\begin{array}{r}3,680 \\
1,783 \\
350\end{array}$ & $\begin{array}{r}31 \cdot 16 \\
19.26 \\
3.78\end{array}$ & 26 & \begin{tabular}{|l}
$299 \cdot 77$ \\
98.57 \\
19.33
\end{tabular} & $\begin{array}{r}33.60 \\
15.44 \\
3.03\end{array}$ & $\begin{array}{r}16,370 \\
8 \cdot 654 \\
1,697\end{array}$ & $\begin{array}{r}55.94 \\
24.27 \\
4 \cdot 76\end{array}$ & 25 & $\mid \begin{array}{c}181.6 \\
68.93 \\
13.79\end{array}$ & $\begin{array}{r}19.36 \\
10.40 \\
2.08\end{array}$ & $\begin{array}{r}12,702 \\
8,492 \\
1,698\end{array}$ & $\begin{array}{r}71.32 \\
38.33 \\
7.67\end{array}$ & 12 & & & & & 15 & & & & \\
\hline 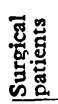 & $\left\{\begin{array}{l}\text { No. } \\
\text { Mean } \\
\text { S.D. } \\
\text { S.E. }\end{array}\right.$ & 15 & \begin{tabular}{|r|}
119.47 \\
49.72 \\
12.84
\end{tabular} & $\begin{array}{l}5.70 \\
4.00 \\
1.03\end{array}$ & \begin{tabular}{|r|}
3,406 \\
1,908 \\
493
\end{tabular} \mid & $\begin{array}{r}30.96 \\
22.87 \\
5.91\end{array}$ & & \begin{tabular}{|}
$276 \cdot 87$ \\
97.34 \\
25.13
\end{tabular} & $\begin{array}{r}31 \cdot 19 \\
15 \cdot 24 \\
3.94 \\
\mid\end{array}$ & $\begin{array}{r}17,957 \\
10,838 \\
2,798\end{array}$ & $\begin{array}{r}64.61 \\
28.22 \\
7.29\end{array}$ & 14 & $\begin{array}{r}175.57 \\
70.01 \\
18.71\end{array}$ & $\begin{array}{r}19.82 \\
9.77 \\
2.61\end{array}$ & $\begin{array}{r}16,214 \\
9,653 \\
2,580\end{array}$ & \begin{tabular}{|l|}
93.36 \\
37.97 \\
10.15
\end{tabular} & 12 & \begin{tabular}{|}
65.92 \\
33.15 \\
9.57 \\
\end{tabular} & 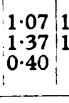 & $\begin{array}{r}1,148 \\
1,611 \\
465\end{array} \mid$ & $\begin{array}{r}12.88 \\
14.89 \\
4.30\end{array}$ & 13 & $\begin{array}{r}163.67 \\
65.67 \\
16.96\end{array}$ & $\begin{array}{r}10.33 \\
6.88 \\
1.78\end{array}$ & $\left|\begin{array}{l}9,883 \\
7,010 \\
1,810\end{array}\right|$ & $\begin{array}{r}60 \cdot 3: \\
31 \cdot 6 \\
8 \cdot 1\end{array}$ \\
\hline
\end{tabular}


achieve significance, though the mean intrinsic factor output was lower and the concentration higher in the medical vagotomy hour. The detailed results (Table III) show the very marked individual variations in response.

Surgical Vagotomy.-The effect of surgery on basal secretion was a significant reduction in mean values for volume, acid, and intrinsic factor $(\mathrm{P}<0.01)$ and for intrinsic factor concentration $(P<0.05)$. The effect of surgery on histamine-stimulated secretion was a significant reduction in mean values for volume, acid $(P<0.01)$, and intrinsic factor output $(P<0.05)$, but there was no significant change in mean values for intrinsic factor concentration. Patients having gastrojejunostomy did

\section{Discussion}

The object of this study was to determine and compare the effects of medical and surgical vagotomy on gastric secretory function with particular emphasis on intrinsic factor secretion, and discussion of the results is limited to these points.

During the course of the study Bitsch et al. (1966) published their findings on the effects of surgical vagotomy on gastric secretory function, and comparison of the two sets of results is desirable. The mean values for volume, acid, intrinsic factor, and intrinsic factor concentration found by us are less than those of Bitsch et al., but the data given in their paper do not

TABLE IV.-Values for Acid and Intrinsic Factor for the Hour After Histamine Stimulation, Before and After Operation, and also During Medical Vagotomy. The Differences are Shown as a Percentage of the Value in the Preoperative Histamine Hour

\begin{tabular}{|c|c|c|c|c|c|c|c|c|c|c|}
\hline \multirow{3}{*}{ Case No. } & \multicolumn{2}{|c|}{$\begin{array}{l}\text { Preoperative Augmented } \\
\text { Histamine Hour }\end{array}$} & \multicolumn{2}{|c|}{$\begin{array}{c}\text { Preoperative Medical } \\
\text { Vagotomy Hour }\end{array}$} & \multicolumn{2}{|c|}{$\begin{array}{c}\text { Postoperative Augmented } \\
\text { Histamine Hour }\end{array}$} & \multicolumn{4}{|c|}{ Percentage Change } \\
\hline & \multirow{2}{*}{$\begin{array}{l}\text { Acid } \\
(\mathrm{mEq})\end{array}$} & \multirow{2}{*}{$\stackrel{\text { I.F. }}{\text { (m } \mu \mathrm{g} . \text { Units }}$} & \multirow{2}{*}{$\underset{(\mathrm{mEq})}{\text { Acid }}$} & \multirow{2}{*}{$\stackrel{\text { I.F. }}{(\mathrm{m} \mu \mathrm{g} . \text { Units }}$} & \multirow{2}{*}{$\underset{(\mathrm{mEq})}{\text { Acid }}$} & \multirow{2}{*}{$\begin{array}{l}\text { I.F. } \\
\text { (m } \mu \mathrm{g} . \text { Units }_{\text {nis }}\end{array}$} & \multicolumn{2}{|c|}{ Acid } & \multicolumn{2}{|c|}{ I.F. } \\
\hline & & & & & & & Due to $\mathrm{M}$. Vag. & Due to Op. & Due to $M$. Vag. & Due to Op. \\
\hline $\begin{array}{l}12 \\
13 \\
14 \\
15 \\
16 \\
17 \\
18 \\
19 \\
20 \\
21 \\
22 \\
23 \\
24 \\
25 \\
26\end{array}$ & $\begin{array}{r}7 \cdot 3 \\
48 \cdot 2 \\
21 \cdot 8 \\
24 \cdot 4 \\
16 \cdot 3 \\
20 \cdot 8 \\
15 \cdot 0 \\
36 \cdot 1 \\
56 \cdot 8 \\
43.9 \\
23.9 \\
36 \cdot 2 \\
57.5 \\
24 \cdot 8 \\
34.8 \\
\end{array}$ & $\begin{array}{r}10,931 \\
16,593 \\
6,233 \\
12,765 \\
11,223 \\
13,984 \\
17,280 \\
35,838 \\
29,796 \\
18,589 \\
6,406 \\
12,412 \\
45,021 \\
17,485 \\
14,802 \\
\end{array}$ & $\begin{array}{r}4 \cdot 3 \\
26 \cdot 6 \\
23 \cdot 9 \\
14 \cdot 5 \\
7 \cdot 7 \\
10 \cdot 3 \\
13 \cdot 4 \\
21 \cdot 1 \\
31 \cdot 4 \\
16 \cdot 7 \\
20 \cdot 0 \\
18 \cdot 8 \\
42 \cdot 4 \\
21 \cdot 1 \\
19 \cdot 8 \\
\end{array}$ & $\begin{array}{r}10,174 \\
17,929 \\
11,510 \\
12,705 \\
7,554 \\
13,937 \\
20,613 \\
30,125 \\
13,969 \\
9,466 \\
7,270 \\
38,280 \\
27,381 \\
6,088 \\
\end{array}$ & $\begin{array}{r}6 \cdot 1 \\
20.9 \\
4 \cdot 1 \\
12 \cdot 7 \\
1 \cdot 2 \\
4 \cdot 1 \\
8 \cdot 2 \\
5.8 \\
24 \cdot 6 \\
19 \cdot 6 \\
10.8 \\
5.0 \\
14.6 \\
8.7 \\
8.6 \\
\end{array}$ & $\begin{array}{r}5,872 \\
7,677 \\
1,689 \\
16,770 \\
1,878 \\
4,175 \\
14,497 \\
3,226 \\
24,871 \\
15,961 \\
5,091 \\
4,630 \\
18,166 \\
12,711 \\
11,036 \\
\end{array}$ & $\begin{array}{l}-41.0 \\
-44.8 \\
+9.6 \\
-40.5 \\
-52.7 \\
-50.4 \\
-10.6 \\
-41.5 \\
-44.7 \\
-61.9 \\
-16.3 \\
-48.0 \\
-26.2 \\
-14.9 \\
-43.1\end{array}$ & $\begin{array}{l}-16.4 \\
-56.6 \\
-81.1 \\
-47.9 \\
-92.6 \\
-80.2 \\
-45.3 \\
-83.9 \\
-56.6 \\
-55.3 \\
-54.8 \\
-86.1 \\
-74.6 \\
-64.9 \\
-75.2\end{array}$ & $\begin{array}{l}-6.9 \\
+8.1 \\
+84.6 \\
+13.2 \\
+45.9 \\
-19.3 \\
-42.5 \\
+1.1 \\
-24.8 \\
+47.8 \\
-41.4 \\
-14.9 \\
+56.6 \\
-58.8\end{array}$ & $\begin{array}{l}-47.9 \\
-53.7 \\
-39.4 \\
+31.3 \\
-83.2 \\
-70.1 \\
=16.1 \\
-90.9 \\
-16.5 \\
-14.1 \\
-20.5 \\
-62.6 \\
-59.6 \\
-25.0 \\
-25.4\end{array}$ \\
\hline $\begin{array}{l}\text { All cases } \\
\text { All except } \\
\text { case } 15\end{array}$ & & & & & & & $\begin{array}{l}-37 \cdot 4 \\
-37 \cdot 5\end{array}$ & $\begin{array}{l}-66 \cdot 8 \\
-67 \cdot 9\end{array}$ & $\begin{array}{l}-11.5 \\
-11.5\end{array}$ & $\begin{array}{l}-44 \cdot 9 \\
-48 \cdot 7\end{array}$ \\
\hline
\end{tabular}

not differ from those in whom pyloroplasty was employed as the drainage procedure. Detailed results (Table IV) again showed very marked individual variation in response. The pattern of response to histamine after operation was similar to that found during medical vagotomy (see Chart).
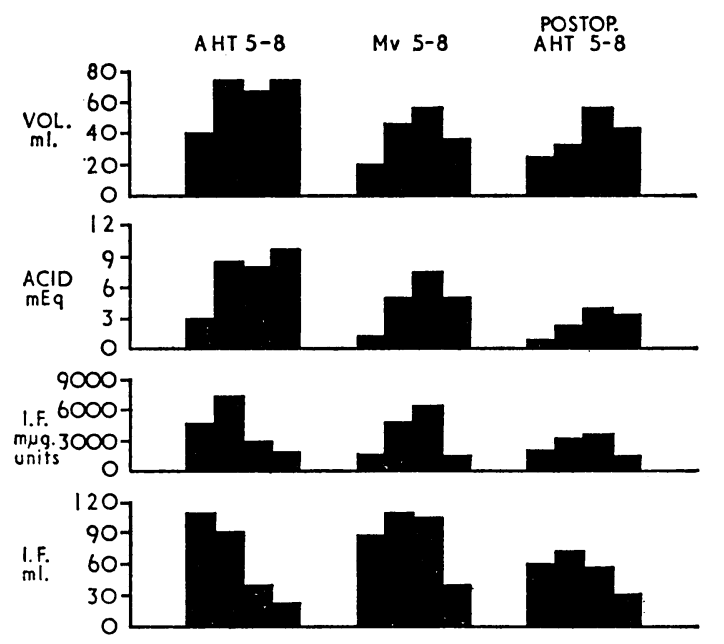

Secretory patterns in cases studied before and after surgery. The figures 5-8 signify the four 15-minute periods after the injection of histamine, 1-4 being the four 15-minute periods before the injection.

Comparison of Effects of Medical and Surgical Vagotomy.Comparison of the mean hourly values after medical vagotomy and after histamine stimulation in the postoperative period showed that the mean values for volume and intrinsic factor did not differ significantly $(P>0.05)$ but that the mean values for acid and intrinsic factor concentration were significantly less $(\mathrm{P}<0.01$ and $<0.05$ respectively) after operation than after medical vagotomy. permit calculation of the significance of these differences. The results can be compared, however, by taking the difference between the values obtained in the histamine hour before and after operation and expressing the difference as a percentage of the preoperative value. Bitsch et al. observed a volume reduction of $46.7 \%$, an acid reduction of $62.5 \%$, and a reduction in intrinsic factor output of $43.8 \%$ (not $34 \%$ as printed in their paper). The corresponding values in the present study are $40.8 \%$ for volume, $66.8 \%$ for acid, and $44.9 \%$ for intrinsic factor. These results are clearly in close agreement and confirm that surgical vagotomy and a drainage procedure effect a significant reduction in the output of gastric juice, acid, and intrinsic factor in response to histamine.

The type of drainage procedure employed does not appear to be important. In our series both groups responded in a similar manner and no significant differences were found between them in regard to volume, acid, or intrinsic factor output after operation. This suggests, but does not prove, that vagotomy is the effective agent.

The effect of medical vagotomy differs sharply from that of surgical vagotomy. The effect of medical vagotomy was a significant reduction in volume and acid output after histamine stimulation, as was expected (Gillespie and Kay, 1961), but an insignificant change in intrinsic factor output. This finding is of interest in relation to the mechanisms which control intrinsic factor secretion. Hoedemaeker et al. (1964) have produced evidence from immunological and autoradiographic studies that the site of secretion is the parietal cell, and this view is supported by the close correlation between amounts of acid and intrinsic factor secreted (Ardeman, 1965 ; Irvine, 1965 ; Rødbro, et al., 1965). The pattern of acid and that of intrinsic factor secretion differ, however, the difference being most obvious on continued histamine stimulation when the output of acid remains high and that of intrinsic factor falls off rapidly after an initial rise (Irvine, 1966 ; Lawrie and Anderson, 1967). This indicates either that the two secretions come from different cells or that they come from the same cell, in which case the 
secretion of acid is by a process of true stimulation and that of intrinsic factor is one of release or "washout." The importance of vagal control is clearly shown by the effect of surgical vagotomy as found by Bitsch et al. (1966) and confirmed here.

That medical vagotomy did not have a quantitatively significant effect on the histamine-stimulated output of intrinsic factor was therefore unexpected but is not necessarily evidence against the concept of vagal control of intrinsic factor secretion. The pattern of intrinsic factor secretion is affected by medical vagotomy in the same way as by surgical vagotomy, suggesting that both procedures exert an effect on the controlling mechanisms even if the effect is quantitatively insignificant with one but not with the other. There are two possible explanations. First the vagal component of acid secretion may be more dominant than the vagal control of intrinsic factor secretion, and since medical vagotomy is less complete than surgical vagotomy the quantitative effect will be correspondingly less. Other influences on intrinsic factor secretion, such as intragastric reflexes, may be more important than the vagal component. Secondly, the medical vagotomy differs from surgical vagotomy in that it fails to block histamine-stimulated washout effect while having a blocking effect on the pattern of active secretion stimulated by histamine.

\section{Summary}

The effect of medical and surgical vagotomy on intrinsic factor secretion was studied in patients with duodenal ulceration.
Surgical vagotomy brought a significant reduction in both basal and histamine-stimulated output, but medical vagotomy did not significantly affect histamine-stimulated output. The pattern of intrinsic factor secretion in response to histamine was affected in the same manner by medical and surgical vagotomy.

The results suggest either that the vagal component in the control of intrinsic factor secretion is less dominant than the vagal component in acid secretion or that medical vagotomy differs from surgical vagotomy, the former failing to block a washout type of pattern and the latter doing so.

We are grateful to Professor A. W. Kay for advice and encouragement, to Professor T. Ferguson Rodger for facilities in his department, and to Merck Sharp \& Dohme Ltd. for supplies of radioactive cyanocobalamin. We acknowledge with thanks a grant from the Secretary of State for Scotland on the advice of the Advisory Committee on Medical Research.

\section{REFERENCES}

Ardeman, S. (1965). Proc. roy. Soc. Med., 58, 916.

Bitsch, V., Christiansen, P. M., Faber, V., and Rødbro, P. (1966). Lancet, 1,1288 .

Gillespie, I. E., and Kay, A. W. (1961). Brit. med. F., 1, 1557.

Gottlieb, C., Lau, K-S., Wasserman, L. R., and Herbert, V. (1965) Blood, 25, 875.

Hoedemaeker, P. J., Abels, J., Wachters, J. J., Arends, A., and Nieweg, H. O. (1964). Lab. Invest., 13, 1394.

Irvine, W. J. (1965). New Engl. f. Med., 273, 432.

Kay, A. W. (1953). Brit. med. F., 2, 77.

Lawrie, J. H., and Anderson, N.' M. (1967). Lancet, 1, 68.

Rødbro, P., Christiansen, P. M., and Schwartz, M. (1965). Ibid., 2, 1200.

\section{Medical Memoranda}

\section{Hydatidiform Mole and Coexistent Foetus, both with Triploid Chromosome Constitution}

\section{Brit. med. F., 1967, 3, 476-478}

Triploid chromosome complement in man has been described in abortions and also in three living subjects, all of whom were mosaics (Böök and Santesson, 1960 ; Penrose and Delhanty, 1961 ; Delhanty et al., 1961 ; Carr, 1963, 1965 ; Ellis et al., 1963 ; Ferrier et al., 1964 ; Thiede and Salm, 1964 ; Aspillaga et al., 1964 ; Szulman, 1965).

Atkin and Klinger (1962) and Szulman (1965) have reported a case of mole with an associated foetus in which triploidy was found in the molar tissue. Makino et al. (1964) found triploid chromosome complements in three cases of early abortion, where the chorionic villi were swollen and oedematous, forming small vesicles as in hydatidiform mole. Carr (1965) in his later series described a similar case. In none of these molar or molar-like gestations were the clinical features reported.

This paper describes the finding of triploid chromosome complement in a hydatidiform mole and its associated abnormal foetus, the mother showing antepartum and postpartum clinical features of molar pregnancy.

\section{CASE REPORT}

A 22-year-old woman developed severe pre-eclampsia at 17 weeks of gestation in her first pregnancy. She had palpitations, severe dyspnoea, and pain in the right iliac fossa when referred to the Royal Women's Hospital seven weeks later. The haemoglobin had fallen from 13 to $7.1 \mathrm{~g} . / 100 \mathrm{ml}$., though vaginal bleeding had not occurred. The blood pressure was 170/110 and the urine contained $20 \mathrm{~g}$. of protein per litre. The right lower abdomen was tender, but no mass was felt apart from the uterus, which reached to the level of the umbilicus. $X$-ray examination showed a foetal skeleton commensurate with 18 rather than 24 weeks of development; the plasma uric acid was $4.7 \mathrm{mg} . / 100 \mathrm{ml}$. ; urinary oestriol $1.5 \mathrm{mg}$./ 24 hours, and urinary chorionic gonadotrophin $300-400 \mathrm{i} . \mathrm{u} . / \mathrm{ml}$.

After treatment with sedation and hypotensive drugs artificial rupture of the membranes was performed and $300 \mathrm{ml}$. of amniotic

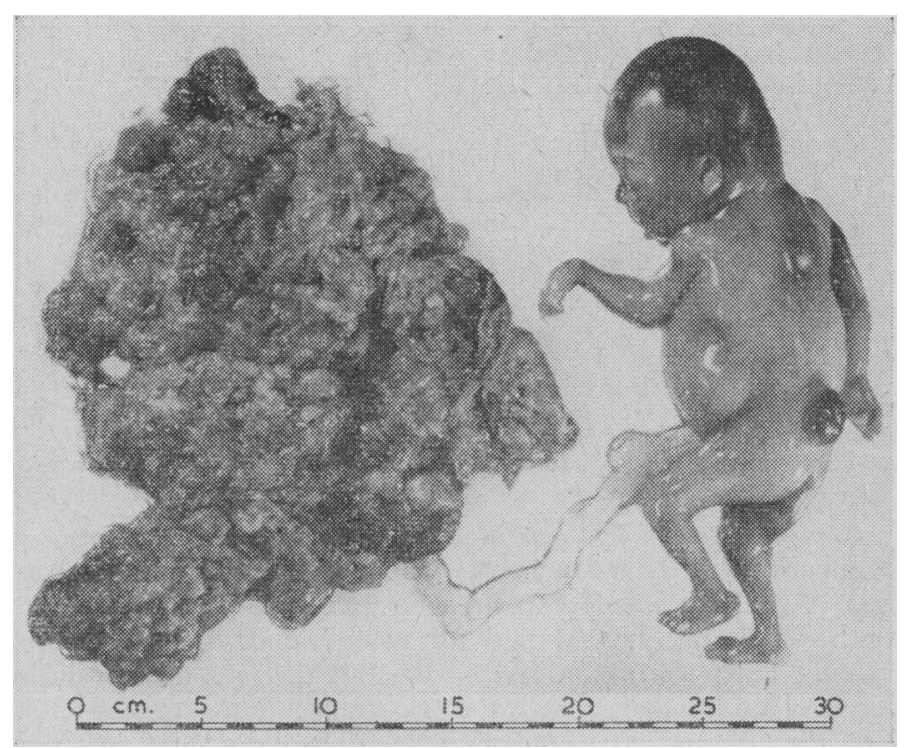

FIG. 1.-Malformed toetus together with placenta showing diffuse macro. scupic molar degeneration. 